\title{
Call for monitoring plan on German GM crops
}

Alison Abbott \& Ulrike Hellerer, Munich

An impasse between government ministers over the cultivation of genetically modified (GM) crops has led the German chancellor, Gerhard Schröder, to intervene. Last week, he asked companies to agree voluntarily to grow their licensed crops only within the framework of a three-year governmentbased research and monitoring programme.

The move came despite unresolved differences within the coalition government over whether such a programme should be carried out - and, if so, how it should be run. Talks between the Social Democrat-led ministries of research and agriculture, both of which generally favour the introduction of commercial agricultural biotechnology, and the Green-led ministries of health and environment, which generally oppose it, are expected to reach agreement on these issues this week.

Speaking at the opening of an exhibition on plant breeding, organized as part of the EXPO 2000 world fair in Hannover, Schröder invited agricultural companies holding, or hoping to hold, licences to grow GM crops to negotiate with the government. These discussions would cover how such a programme should be run, what research should be carried out, which environmental impacts should be monitored, and who should pay.

Confirming that research into the applications of genetic engineering in both health and agriculture remains a government priority, Schröder also said that consumers need to be persuaded of the safety of GM foods, and not forced to accept them.

No details have yet been provided of how an experimental programme might proceed. But according to a spokesman from the Robert Koch Institute (RKI), which licenses field trials for the health ministry, consumer groups, as well as representatives from the non-commercial scientific environment, could eventually become involved. He predicts that the programme will be in place before the start of next year's growing season.

Response from industry, which has been left in a position of great uncertainty after the government blocked the first German commercial licence - for Novartis's insectresistant Bt maize, last February (see Nature 403, 821;2000) — has been positive. Novartis says that it would "expect to participate" in a research programme, and KWS, a major seed manufacturer, said that the programme would provide reassurance to all stakeholders, including industry, environmentalists and consumers.

The RKI itself is keen to participate in the government-level programme. It has long and vociferously complained about its advice being ignored by the health ministry, despite its legal status as the ministry's official scientific advisor. It had, for example, advised the

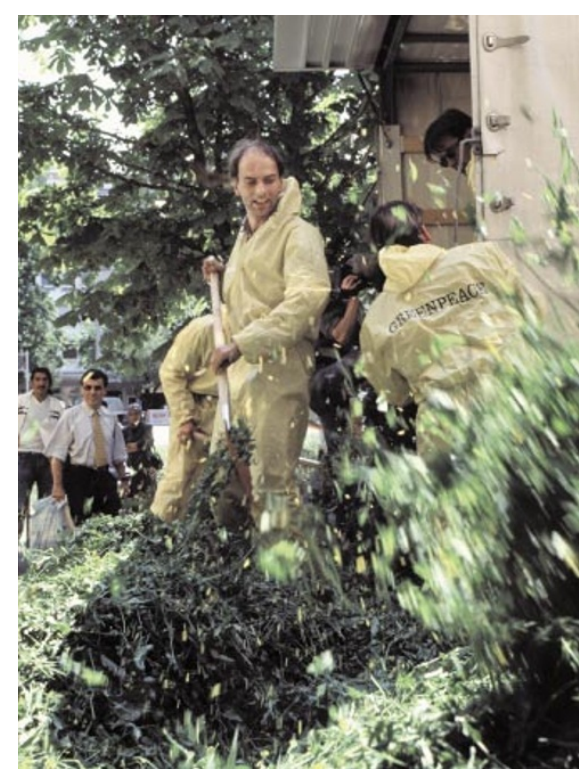

Green reaper: protesters last week dumped GM rapeseed at the German environment ministry.

ministry that there were no scientific grounds to block Novartis's commercial licence.

The new monitoring programme would bear some similarities to the farm-scale GM plant trials being run jointly by industry and the Department of the Environment, Transport and the Regions in the United Kingdom. But Schröder's plan, according to the RKI, will not necessarily imply a moratorium on commercial cultivation. Instead it will be part of "a slow and careful introduction of farm-scale production". Nor will it necessarily involve destruction of the crops after the test period, as happens in the United Kingdom. Instead, the crops might be used to test processing techniques.

But environmentalists are far from happy. Stefan Flothmann, spokesman for Greenpeace's gene technology campaign in Germany, dismisses the move as simply a way for the government to win time for consumers to become accustomed to gene technology. Greenpeace is fundamentally opposed to any deliberate release of GM organisms.

Beatrix Tappeser, coordinator of genetic engineering studies for the independent Öko Institute in Freiburg, an institute critical of agricultural biotechnology and which has the ear of the health ministry, says that "sufficient field trials of GM crops have already been conducted to demonstrate the dangers of gene transfer to the environment".

Without any details of the plan, says Tappeser, it is impossible to judge whether the programme suggested by Schröder could be helpful. But she points out that the environmental monitoring in such a programme should not be left to industry, or industryfinanced researchers. "To win public confidence, monitoring needs to be conducted by all stakeholders," including environmental and consumer groups, she says.

\section{'Dolly' team wins further patents}

\section{Peter Aldhous, London}

The creators of Dolly the sheep have been awarded two more British patents on the 'nuclear transfer' technology that is the key to cloning. The patents should strengthen the position of the Dolly team, based at the Roslin Institute near Edinburgh, and of the companies that licensed its technology, in a highly competitive area.

In nuclear transfer cloning, a donor cell is fused with a recipient egg cell that has been stripped of its chromosomes. In January this year, the Roslin Institute won two British patents on cloning using donor cells that had been starved into a state of 'quiescence' - originally thought to be important for successful cloning.

By that time, however, rivals at the University of Massachusetts in Amherst had already been awarded a US patent covering cloning from non-quiescent cells, and had licensed this technology to Advanced Cell Technology, a company in nearby Worcester (see Nature 405, 610-612; 2000).

The new Roslin patents focus on techniques to allow the donor nucleus to remain in contact with the recipient egg's cytoplasm for several hours before 'activating' the egg — starting its embryonic development using a pulse of electric current. "This is the other half of the nuclear transfer story," says David Earp, vice-president for intellectual property at Geron of Menlo Park, California, which has acquired the rights to exploit Roslin's cloning technology.

As the new patents do not depend on the donor cell being quiescent, they extend the Roslin team's claims. But just how powerful they prove to be remains to be seen.

The Roslin team argues that delayed activation can increase the efficiency of cloning, and in some species may be essential to achieve live births. But other groups say they can clone successfully without infringing the new patents. Goats, for instance, have been cloned by activating the egg during fusion with the donor cell (Nature Biotech. 17, 456-461; 1999). 